\title{
RESEARCH
}

\section{A Linkage Map of the Ovine X Chromosome}

\author{
Susan M. Galloway, ${ }^{1,3}$ Vickie Hanrahan, ${ }^{1}$ Ken G. Dodds, ${ }^{2}$ \\ Michelle D. Potts, ${ }^{1}$ Allan M. Crawford, ${ }^{1}$ and Diana F. Hill ${ }^{1}$
}

\author{
${ }^{1}$ AgResearch Molecular Biology Unit, Department of Biochemistry and Centre for Gene Research, \\ University of Otago, Dunedin, New Zealand; ${ }^{2}$ AgResearch, Invermay Agricultural Centre, \\ Mosgiel, New Zealand
}

A genetic linkage map of the ovine $X$ chromosome containing type $I$ and type II markers has been constructed. The map contains 7 known gene markers and 14 microsatellite markers with a recombination length of $141.9 \mathrm{cM}$. Segregation of polymorphic markers was observed in a three-generation pedigree containing 480 animals. The maximum number of informative meioses was 912 . Additional information was obtained for some markers by following segregation in the AgResearch International Mapping Flock, consisting of nine three-generation full-sib pedigrees. A pseudoautosomal region containing two markers has been identified at one end of the linkage map. Comparisons with mouse and human $\mathrm{X}$ chromosomes confirms the observation of Ohno (1973) that the gene content of the mammalian X chromosome is retained. In particular, the conserved grouping of the genes PHKAl, ATP7A, and XIST observed in both the human and the mouse $X$ chromosome appears to be conserved in the sheep $X$ chromosome, and XIST has been mapped to near the center of the chromosome. This study provides the first reported genetic linkage map combining both type I and type II markers for any ruminant $\mathrm{X}$ chromosome.

Until very recently, the $\mathrm{X}$ chromosomes of placental mammals were considered to be constrained by Ohno's rule (Ohno 1973), which postulated that genes on the $\mathrm{X}$ chromosome of one mammal would be on the $\mathrm{X}$ chromosomes of all other mammals. This rule was refined with the discovery that several genes on the short arm of the human $\mathrm{X}$ chromosome (Xp) are autosomal in marsupials and monotremes (McKay et al. 1992; Fitzgerald et al. 1993; Graves and Foster 1994). The apparent conservation of gene content of the $\mathrm{X}$ chromosomes was thought to be related to the requirement of $\mathrm{X}$-inactivation in females for dosage compensation. The only known exception to this conservation in placental mammals has been a chloride channel gene (CLCN4), which has been shown recently to map to the $\mathrm{X}$ chromosome in humans and Mus spretus mice, but to chromosome 7 in C57BL/6 mice (Palmer et al. 1995; Rugarli et al. 1995). The X chromosomes of humans and mice are the most well-characterized and many known X-linked genes and other unique DNA sequences have been mapped in these species (Herman et al. 1994; Willard et al. 1994). Based on mapped gene orders, evolutionary relationships between mice and human $\mathrm{X}$

${ }^{3}$ Corresponding author.

E-MAIL galloways@agresearch.cri.nz; FAX 64-3-477-5413. chromosomes have been explained by five breakpoints and rearrangement of the resulting six blocks of genes (Amar et al. 1988). This concept has been refined recently to accommodate eight conserved segments with seven breakpoints (Blair et al. 1994, 1995). It is of interest to determine whether the conserved blocks of genes identified in humans and mice remain conserved in other mammalian species, and whether the conservation of these groups has been maintained throughout evolution.

The $\mathrm{X}$ chromosomes of mammalian species other than human and mouse are less wellcharacterized. In cattle, the genes DMD (Duchenne muscular dystrophy, Xq31-q33), F9 (coagulation factor 9, Xq33-q34), PGK1 (phosphoglycerate kinase 1, Xq21-q22), ZFX (X-linked zinc finger protein, Xp21), G6PD (glucose-6-phosphate dehydrogenase), GLA ( $\alpha$-galactosidase), and HPRT (hypoxanthine phosphoribosyl transferase) have been mapped by in situ hybridization or somatic cell hybrids (Fries et al. 1993). The most comprehensive linkage map of the bovine X chromosome (Yeh et al. 1996) contains the following 15 linked microsatellite markers spanning $118 \mathrm{cM}$ : BM6017, TGLA89, TEXAN13, TGLA128, BM2713, BM4604, BR215, TGLA68, BM4321, HEL14, TGLA15, INRA120, TGLA325, MAF45, and INRA30. In addition, the microsat- 


\begin{tabular}{|c|c|c|c|c|c|}
\hline Locus name & Symbol & Species & $P I^{\mathbf{a}}$ & $\begin{array}{l}\text { Informative } \\
\text { meioses }\end{array}$ & Reference \\
\hline \multicolumn{6}{|l|}{ ATPase, $\mathrm{Cu}^{2+}$ transporting, } \\
\hline Duchenne muscular dystrophy & DMD & human & $0.375^{\star}$ & 556 & this study \\
\hline Phosphorylase kinase $\alpha-1$ & PHKA1 & rabbit & $0.341^{*}$ & 527 & Potts et al. (1994a) \\
\hline Myelin proteolipid protein & PLP & cattle & 0.523 & 732 & Sise et al. (1992) \\
\hline Pyruvate dehydrogenase E1 & & & & & \\
\hline Thyroxine-binding globulin & $\begin{array}{l}\text { PDHAI } \\
\text { TBG }\end{array}$ & $\begin{array}{l}\text { human } \\
\text { human }\end{array}$ & $\begin{array}{l}0.291^{\star} \\
0.501\end{array}$ & $\begin{array}{l}635 \\
736\end{array}$ & $\begin{array}{l}\text { this study } \\
\text { Hanrahan et al. (1992) }\end{array}$ \\
\hline Inactive $\mathrm{X}$-specific transcript & XIST & cattle & 0.464 & 269 & van Stijn and Galloway (1995) \\
\hline
\end{tabular}

ellite markers AGLA257, ETH123, and TGLA328 (Bishop et al. 1994) and the VNTR marker GMBT027 (DXS1) (Fries et al. 1993) have been assigned by linkage methods but are not part of an ordered genetic linkage map. Two unrelated linkage maps of the pig X chromosome contain 11 linked porcine microsatellite or minisatellite markers (Rohrer et al. 1994; Archibald et al. 1995; Yerle et al. 1995) and no known genes. A preliminary linkage map of the rat $\mathrm{X}$ chromosome (Jacob et al. 1995) contains 11 markers for 8 loci and includes four known genes.

To date, 15 loci have been localized to the sheep X chromosome. ARAF1 (v-raf oncogene homolog 1), GLA, G6PD, HPRT, OTC (ornithine transcarbamoylase), PGK1, PLP (myelin proteolipid), RCP (red cone pigment), SYN1 (synapsin 1), and ZFX have been assigned using sheep $\times$ hamster somatic cell hybrids (SaidiMehtar et al. 1981, 1989; Aasen and Medrano 1990). The Fec $X^{I}$ fecundity gene segregates with the ovine X chromosome (Davis et al. 1991), MAF45 has been mapped to the pseudoautosomal region (Swarbrick et al. 1992), and TBG (thyroxine binding globulin) has been linked to PLP (Sise et al. 1994). A restriction fragment length polymorphism (RFLP) for F8C (coagulation factor VIIIC, Cf8) has been linked to hemophilia A disease in White Alpine sheep and in situ hybridization has assigned it to the long arm at Xq24Xq33 (Backfisch et al. 1994). F8C is the only one of these markers with a known regional location.
We report here a linkage map of the ovine $\mathrm{X}$ chromosome consisting of 7 known gene markers and 14 microsatellite markers and therefore provide information about the relative positions of 21 loci.

\section{RESULTS}

Mammalian X-linked markers to $>28$ known gene loci were obtained and tested for homology with sheep DNA. The majority of these were eliminated from the study because they did not hybridize to sheep DNA under defined stringency conditions, showed repeated elements or autosomal components that made interpretation of inheritance of alleles impossible, or did not identify polymorphic bands in sheep DNA cut with up to 24 different restriction enzymes (see Methods).

The gene probes that were polymorphic in sheep are listed in Table 1. PDHA1 identified several constant bands in sheep DNA cut with HindIII, which probably represent a combination of $\mathrm{X}$-linked and autosomal bands (Dahl et al. 1990) but was included on the map because two Xlinked alleles were able to be scored through the sheep pedigrees. Most microsatellite markers from cattle were polymorphic in sheep and these provided the basis of our microsatellite markers (Table 2). Three new sheep microsatellite markers (OarAE25, OarAE133, and OarCP131) were derived from genomic sheep DNA as part of the 


\begin{tabular}{|c|c|c|c|c|c|c|}
\hline $\begin{array}{l}\text { Marker } \\
\text { name }\end{array}$ & Primer Sequences $\left(5^{\prime}-3^{\prime}\right)$ & $\begin{array}{l}\text { Annealing } \\
\text { tempera- } \\
\text { ture }\end{array}$ & $\begin{array}{l}\text { Number } \\
\text { of alleles }\end{array}$ & PIC & $\begin{array}{l}\text { Informative } \\
\text { meioses }\end{array}$ & Reference \\
\hline BM861 & $\begin{array}{l}\text { TTGAGCCACCTGGAAAGC } \\
\text { CAAGCGGTTGGTTCAGATG }\end{array}$ & $55^{\circ} \mathrm{C}$ & 4 or 5 & 0.427 & 171 & Bishop et al. 1994 \\
\hline INRA30 & $\begin{array}{l}\text { ATGCAAATCTGCTAAATCACCTAT } \\
\text { CCCAACTCTCACATCCAGAT }\end{array}$ & touchdown & 3 & 0.401 & 186 & Ciampolini et al. 1993 \\
\hline ILSTS017 & $\begin{array}{l}\text { GTCCCTAAAATCGAAATGCC } \\
\text { GCATCTCTATAACCTGTTCC }\end{array}$ & $63^{\circ} \mathrm{C}$ & 9 & $0.699^{\mathrm{a}}$ & 693 & Kemp et al. 1993 \\
\hline MAF45 & $\begin{array}{l}\text { ATTGACACTTCAGTAAGTTAACAATGG } \\
\text { CAGACACAACTGAGCAACTAGCGC }\end{array}$ & $60^{\circ} \mathrm{C}$ & 11 & 0.790 & 778 & Swarbrick et al. 1992 \\
\hline OarAE25 & $\begin{array}{l}\text { AATCTAAGTGTTCATCAATAGATGAATGG } \\
\text { GTGGCTAACACAGCAATGGG }\end{array}$ & $65^{\circ} \mathrm{C}$ & 8 & 0.757 & 764 & Hanrahan et al. 1994 \\
\hline OarAE133 & $\begin{array}{l}\text { AGCCAGTAGGCCCTCACCAGG } \\
\text { CCAACCATTGGCAGCGGGAGTGTGG }\end{array}$ & $65^{\circ} \mathrm{C}$ & 12 & 0.629 & 860 & Hanrahan et al. 1994 \\
\hline OarCP131 & $\begin{array}{l}\text { ATGTGCCACAACTAAGACCAGCAC } \\
\text { CCAGGGAAGTCCCATACAATTAACC }\end{array}$ & $63^{\circ} \mathrm{C}$ & 8 & 0.832 & 209 & this study \\
\hline OarMP4 & $\begin{array}{l}\text { GTCTTGTCCATCCATACAAGGG } \\
\text { GGCAGATTCTTTACCACTGAGCC }\end{array}$ & $63^{\circ} \mathrm{C}$ & 6 & 0.778 & 806 & this study \\
\hline TGLA15 & $\begin{array}{l}\text { GGTGACTGTACAACACTGTGAATG } \\
\text { TAGGCTATGGTCCAAGGGTTCAC }\end{array}$ & $60^{\circ} \mathrm{C}$ & 4 & 0.666 & 770 & Georges and Massey 1992 \\
\hline TGLA54 & $\begin{array}{l}\text { CTCAATATTTTGCAATAACATATAAGG } \\
\text { ACGATATCATGTTAGTTTCAGGTG }\end{array}$ & $63^{\circ} \mathrm{C}$ & 3 & $0.516^{\mathrm{a}}$ & 556 & Georges and Massey 1992 \\
\hline TGLA68 & $\begin{array}{l}\text { ATCTTACTTACCTTCTCAGAGCT } \\
\text { GGGACAAAATTTTACATATACACTT }\end{array}$ & $55^{\circ} \mathrm{C}$ & 2 & $0.370^{\mathrm{a}}$ & 556 & Georges and Massey 1992 \\
\hline TGLA72 & $\begin{array}{l}\text { ATGGGTGGGTCTGAATGAGGTGG } \\
\text { GGGCATGAGTAGGTATTTCACAGG }\end{array}$ & $60^{\circ} \mathrm{C}$ & 5 & $0.572^{\mathrm{a}}$ & 581 & Georges and Massey 1992 \\
\hline TGLA89 & $\begin{array}{l}\text { GTGTTATAACAGAAAGTTCTCATTA } \\
\text { TATTGCAGGCAGACTCTTTACC }\end{array}$ & $60^{\circ} \mathrm{C}$ & 5 & $0.686^{\mathrm{a}}$ & 551 & Georges and Massey 1992 \\
\hline TGLA328 & $\begin{array}{l}\text { AAAGAAAGGCTGATATTGTAGCATC } \\
\text { CTAACTGTGAGATTGCTTTGTAGTA }\end{array}$ & $50^{\circ} \mathrm{C}$ & 4 & 0.664 & 175 & Georges and Massey 1992 \\
\hline \multicolumn{7}{|c|}{$\begin{array}{l}\text { Markers derived from sheep are MAF } 45 \text { and all markers prefixed Oar. All others were derived from cattle. } \\
\text { TCLA primer sequences were designed from the sequence provided in the patent (Georges and Massey 1992) and may be different } \\
\text { from the published bovine primer sequences for the same marker. } \\
\text { Polymorphic information content (PIC, Botstein et al. 1980) was calculated from the allele frequencies detected in } 17 \text { unrelated } \\
\text { animals comprising the grandparents of the AgResearch International Mapping Flock (Crawford et al. 1995) or the allele frequen- } \\
\text { cies in } 35 \text { unrelated Romney and Coopworth female sheep (a). } \\
\text { (Touchdown) touchdown PCR annealing procedure } 60^{\circ} \mathrm{C} \times 3,57^{\circ} \mathrm{C} \times 3,54^{\circ} \mathrm{C} \times 3,51^{\circ} \mathrm{C} \times 3,48^{\circ} \mathrm{C} \times 20 \text {. }\end{array}$} \\
\hline
\end{tabular}

marker isolation strategy used for the construction of the sheep linkage map (Crawford et al. 1995) and one (OarMP4) was derived from a hamster somatic cell hybrid containing part of the sheep X chromosome (Burkin et al. 1993).
All of the markers described here are newly positioned on the sheep $\mathrm{X}$ chromosome with the exception of MAF45 (Swarbrick et al. 1992). OarAE25, OarAE133, PHKA1, ATP7A, PLP, TBG, and XIST (Tables 1 and 2) have been shown pre- 


\section{GALLOWAY ET AL.}

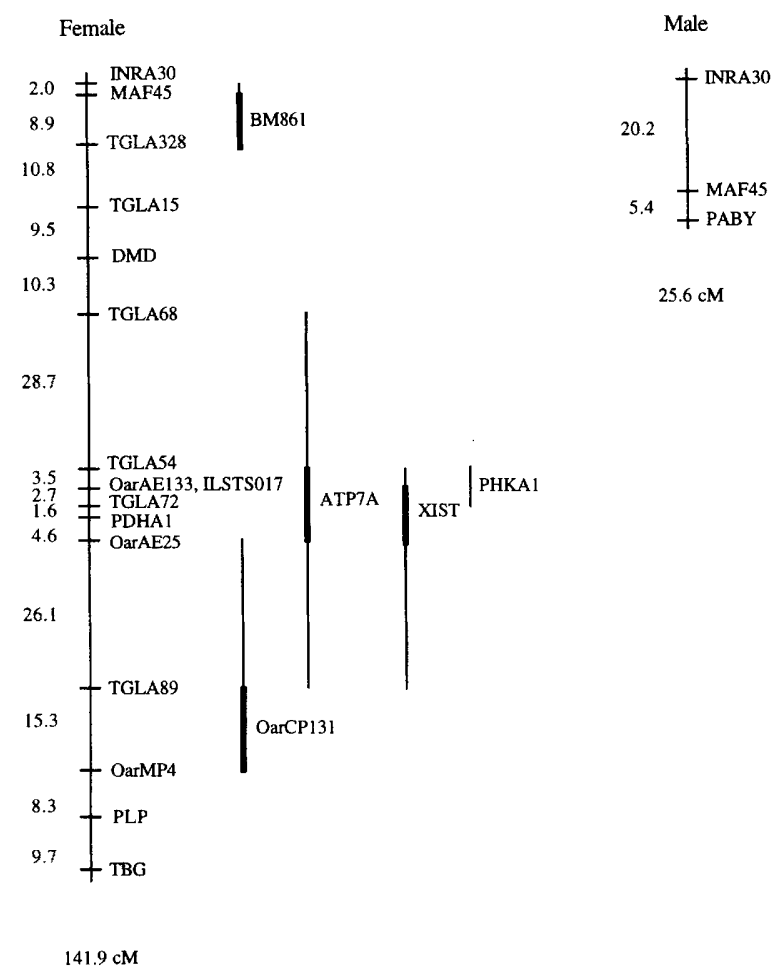

Figure 1 Genetic linkage map of the sheep $X$ chromosome. Markers shown to the right of the main framework map were significantly linked to the group but could not be positioned on the framework at odds $>1000: 1$. A vertical line indicates the intervals supported at the lod-3 level and the solid bar indicates intervals supported at the lod- 1 level (odds $>10: 1$ ). The distances (in $\mathrm{CM}$ ) are shown for female and male and were estimated using the Kosambi mapping function. PABY indicates the $Y$ chromosome pseudoautosomal boundary.

viously to be $\mathrm{X}$-linked in sheep by this laboratory but not mapped to specific locations. The identification of RFLPs with human cDNA probes for DMD and PDHA1, and the isolation of the sheep microsatellites OarMP4 and OarCP131 are described for the first time here. In addition, nine cattle microsatellite markers (BM861, INRA30, ILSTS017, TGLA15, TGLA54, TGLA68, TGLA72, TGLA89, and TGLA328) have been amplified successfully in sheep and included in this map. INRA30 and MAF45 amplify two alleles in male sheep and map to the pseudoautosomal region. BM861 was identified originally as being on the $Y$ chromosome in cattle (Bishop et al. 1994), but we identified alleles in sheep that segregated with the $X$ chromosome as well as male-specific bands. All of the other markers were X-linked and only showed one segregating allele in males.
The present female sex-specific linkage map of the sheep X chromosome contains 16 ordered markers spanning $141.9 \mathrm{cM}$ (Fig. 2, below). The most likely positions of the five loci not ordered on the framework map are indicated by solid bars. The markers include seven cDNA probes to known genes on mammalian $\mathrm{X}$ chromosomes (Table 1) and 14 microsatellite markers from sheep and cattle (Table 2). The male linkage map indicates the position and approximate extent of a pseudoautosomal region from INRA30 to beyond MAF45. In the male, no recombination was observed between markers from BM861 to TBG. No male heterozygotes were observed for these markers; therefore they must lie outside the pseudoautosomal region, suggesting that the pseudoautosomal boundary lies between MAF45 and BM861. The observation that meiotic recombination of $\mathrm{X}$ and $\mathrm{Y}$ chromosomes in male sheep occurs at the centromeric end of the $\mathrm{X}$ chromosome (Dai et al. 1994) provides strong evidence that this linkage map can be oriented on the physical chromosome with INRA30 and MAF45 near the centromere. The recombination length of the male $\mathrm{Y}$ chromosome pseudoautosomal region between INRA30 and MAF45 is $~ 10$ times longer than the corresponding region of the female $\mathrm{X}$ chromosome.

The linkage map is $141.9 \mathrm{cM}$ and appears to cover a considerable proportion of the sheep $\mathrm{X}$ chromosome. Mammalian X chromosomes are estimated to have a physical length of $5 \%$ of the average mammalian genome (Ohno 1973). The total sheep genome has been estimated to have a minimum length of $2770 \mathrm{cM}$ (Chapman and Bruere 1977), which predicts a minimum length for the $\mathrm{X}$ chromosome of $139 \mathrm{cM}$. The relative positions of the known genes mapped to the sheep $\mathrm{X}$ chromosome are compared with the same genes on human, mouse, and cattle chromosomes in Figure 2. XIST, PHKA1, and ATP7A are all located close to each other in the sheep as well as in both human and mouse $\mathrm{X}$ chromosomes. PLP and TBG are relatively close in the sheep and in the human. TBG has not been mapped in the mouse. PDHA1 is mapped to near the XIST/PHKA1/ATP7A cluster in sheep.

\section{DISCUSSION}

This study provides the first reported genetic linkage map combining both type I and type II markers (O'Brien 1993) for any ruminant $X$ chromosome. The presence of known gene markers 


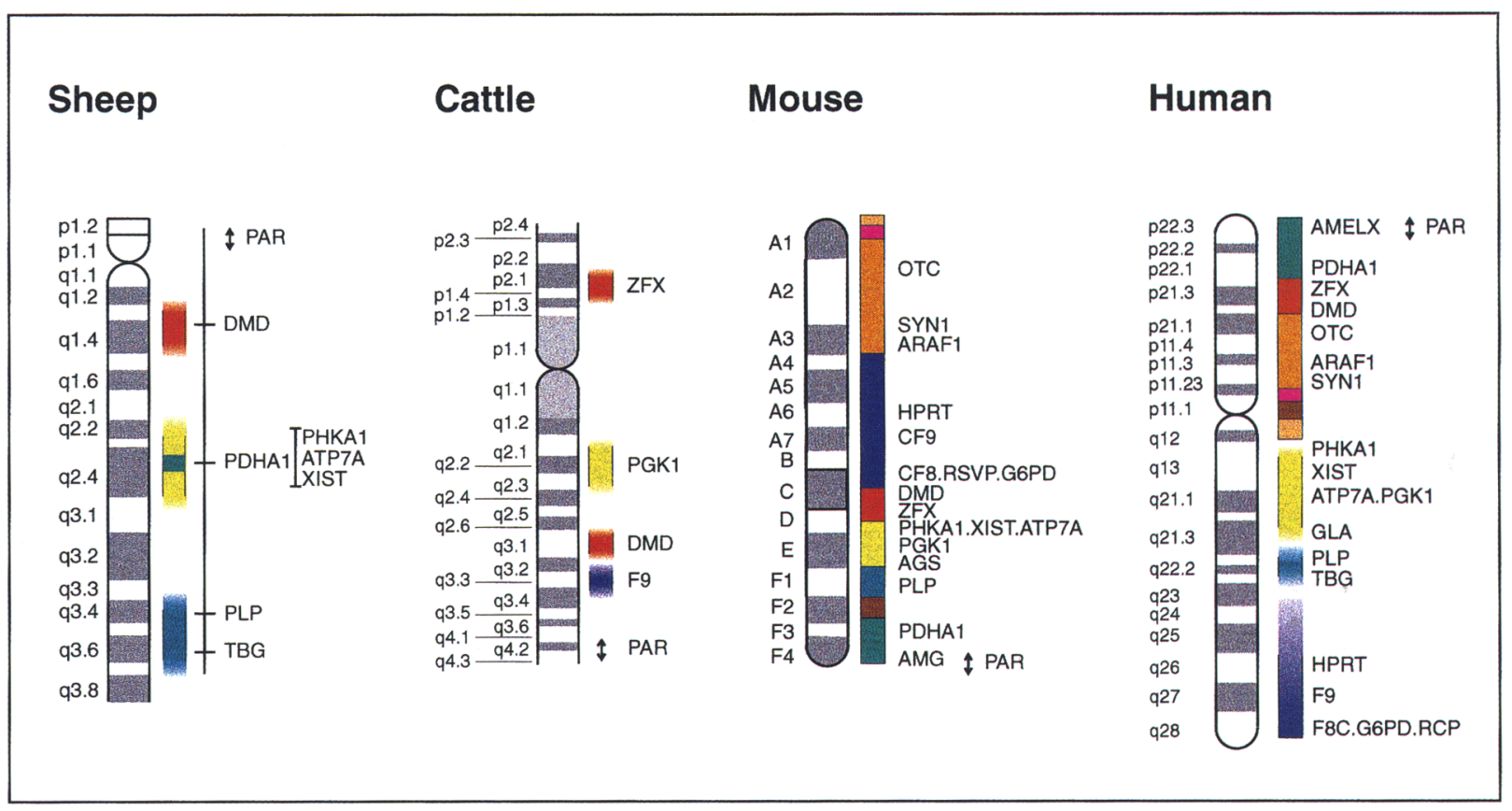

Figure 2 Comparison of the genes on the sheep $X$ chromosome with the homologous segments of the cattle, mouse, and human chromosomes. Only those genes that have been shown to map to the sheep or cattle $X$ chromosome have been indicated on the mouse and human chromosomes [with the exception of AMELX (AMG)]. Genes on the sheep linkage map are shown beside the karyotype of the sheep $X$ chromosome with the pseudoautosomal region oriented beside the centromeric $p$ arm. The relative scale has been drawn to indicate that the linkage map probably covers most of the length of the physical chromosome, but no direct evidence is available to align the ovine physical and linkage maps. The pseudoautosomal region (PAR) is indicated by a double-headed arrow. Colored sections indicate the extent of the nine blocks of genes (Blair et al. 1994, 1995) that rearrange between the mouse and the human $X$ chromosomes. These have also been indicated on the sheep linkage map and cattle chromosome where applicable. Mapping data is from sheep (this study), cattle (Echard et al. 1994), mouse (Herman et al. 1994), and human gene locations from the GDB Human Genome Data Base (Johns Hopkins University, Baltimore, MD) on July 18, 1995 at 3:54 pm Eastern time. The position of the cattle pseudoautosomal region is from Yeh et al. (1996).

(type I) allows comparison of this map with human and mouse $X$ chromosome maps. All seven gene markers reported here have mapped homologs in humans, and all but TBG have mapped homologs in mice. The microsatellite markers (type II) on this map (the majority of which are derived from cattle) will assist with comparisons of $\mathrm{X}$ chromosome maps of cattle and goats as they become available. The type II markers in the sheep X chromosome map are generally highly polymorphic, which makes them useful for parentage verification and genetic linkage searches as well as providing cohesion to the map.

The ovine $\mathrm{X}$ chromosome is the fourth largest sheep chromosome and is submetacentric (Fig. 2). The position of the centromere and the banding pattern of the ovine $\mathrm{X}$ chromosome differs from the human, mouse, and cattle $X$ chromosomes. The human and cattle $\mathrm{X}$ chromosomes are metacentric, whereas the mouse $\mathrm{X}$ chromosome is acrocentric (Fig. 2). Although the X chromosomes of the placental mammals differ in their banding patterns (Fig. 2), the original prediction of Ohno that X-linked genes are conserved in mammals (Ohno 1973) appears to hold true for the genes presently mapped in sheep. However, the order of genes on the human and mouse chromosomes is not conserved. To date eight rearranged blocks of genes have been identified in human and mouse (Laval and Boyd 1993a; Blair et al. 1994, 1995) (Fig. 2), and one gene has been identified that appears to be absent from the $X$ chromosome of the C57BL/6 mouse and reside on chromosome 7 (Palmer et al. 1995; Rugarli et al. 1995). It is clear that certain syntenic regions are conserved between human and mouse X chromosomes (Laval and Boyd 1993b), but as further genes are mapped it is 


\section{GALLOWAY ET AL.}

likely that additional rearrangements will be found.

This linkage map appears to cover most of the sheep X chromosome. Mammalian X chromosomes are estimated to have a physical length of $\sim 168 \mathrm{cM}$, assuming that the $\mathrm{X}$ chromosome comprises $5 \%$ of the average mammalian genome (3300 cM) (Ohno 1973). However, current linkage maps of different mammalian X chromosomes indicate a range of genetic lengths. Estimates for the human $\mathrm{X}$ chromosome range from 191 to $236 \mathrm{cM}$ (Willard et al. 1994), and the mouse $\mathrm{X}$ chromosome appears to be $\sim 80 \mathrm{cM}$ (Herman et al. 1994). The most recent cattle X chromosome linkage map of $119 \mathrm{cM}$ is estimated to be $30-50 \mathrm{cM}$ short, based on physical mapping of two markers to the cattle $\mathrm{X}$ chromosome (Yeh et al. 1996). Our length of $142 \mathrm{cM}$ is close to $5 \%$ of the minimum length estimate for the sheep genome of $2770 \mathrm{cM}$ (Chapman and Bruere 1977) and comparable with the estimated length of the cattle $\mathrm{X}$ chromosome. The ordered markers are spaced relatively evenly along the chromosome with the exception of two gaps of $\sim 25 \mathrm{cM}$. These may be regions with higher recombination rates, but are more likely to reflect a random distribution of markers, as is seen in the ovine autosomal genetic linkage map (Crawford et al. 1995).

The structure of the ovine $\mathrm{X}$ chromosome and relative positions of genes along the chromosome may provide insight into the evolution of the mammalian X chromosomes. Comparison of gene orders on the ovine $X$ chromosome could further identify regions that may be conserved within all placental mammals and help elucidate whether there are some genes that need to be in a particular order, or adjacent to particular genes to function properly. This study has identified one such set of genes. The conserved region in humans and mice that contains PHKA1, XIST, and ATP7A (Menkes disease, $\mathrm{Mnk} / \mathrm{Mo}$ ) is also conserved in sheep (Fig. 2). PHKA1 and XIST have been shown to be physically linked in a $2.6-\mathrm{Mb}$ YAC contig along with RPS4X on the human X chromosome (Lafreniere et al. 1993) and in the mouse, Phka1 and Xist have been mapped within a 2-Mb interval that also contains Rps4 (Cooper et al. 1993). On our map, the most likely positions of PHKA1, XIST, and ATP7A all lie within a 12-cM region that we estimate to be approximately the center of the $\mathrm{X}$ chromosome.

In the female mammal, expression of most genes on the $\mathrm{X}$ chromosome is controlled by $\mathrm{X}$ inactivation to allow for dosage compensation in comparison with the male. The RNA product of the XIST gene has been shown to be a prerequisite for X-inactivation in humans and mice (Brown et al. 1991). The identification of an XIST gene homolog in sheep is the first evidence that the sheep $\mathrm{X}$ chromosome is subjected to $\mathrm{X}$ inactivation in a manner similar to humans and mice. The mechanisms responsible for $\mathrm{X}$ inactivation may place constraints on the positions of genes relative to the $\mathrm{X}$-inactivation center. It is interesting to note that in all three species the XIST gene is located near the center of the chromosome, regardless of the position of the centromere. Conservation of the gene cluster XIST/PHKA1/ATP7A between the three species (sheep, human, and mouse) suggests that there are constraints that require this region to remain intact during evolution. One possibility is that PHKA1 and ATP7A may be close to the XIST gene because of requirements to be inactivated early in the X-inactivation process. Alternatively, importance of the XIST gene for successful X-inactivation may mean that any rearrangements or breakpoints within the immediate vicinity of XIST cannot be tolerated and PHKA1 and ATP7A have remained close as a result.

We have identified one rearrangement in sheep that does not occur in humans and mice. In humans and mice, PDHA1 is far from XIST in a block that contains AMELX/Amg but in sheep, PDHA1 is close to the PHKA1, XIST, ATP7A cluster (Fig. 2). It is impossible to tell from our map whether this block is still one unit in sheep or whether PDHA1 alone has been rearranged to a position near XIST. Another departure from the conserved blocks in mice and humans can be seen in cattle (Fig. 2) where ZFX and DMD have been assigned by in situ hybridization to opposite ends of the chromosome (Echard et al. 1994).

A second similarity with the human $\mathrm{X}$ chromosome is the relatively close linkage of PLP to TBG (Fig. 2), but this cannot be examined as TBG has not been mapped in mice.

Meiotic recombination of the ovine $\mathrm{X}$ chromosome with the ovine $Y$ chromosome has been shown to occur at the centromeric end of the chromosome (Dai et al. 1994) and this is presumed to contain the pseudoautosomal region required for pairing. Based on this observation we have aligned our linkage map with the pseudoautosomal region toward the top (Fig. 1). In the acrocentric mouse X chromosome the pseudoautosomal region is at the opposite end to the centromere. The major pseudoautosomal region in 


\section{OVINE X CHROMOSOME MAP}

humans is at the telomeric end of the p arm, although a much smaller pseudoautosomal region has also been identified at the end of the $\mathrm{q}$ arm (Freije et al. 1992). The position of the pseudoautosomal region in cattle $\mathrm{X}$ chromosome has been located recently at the telomeric end of the long arm by in situ hybridization of the pseudoautosomal marker INRA30 (Yeh et al. 1996), although previous reports placed it at the end of the short arm of the cattle $X$ chromosome (Barendse et al. 1994; Eggen and Fries 1995). Comparison of the four $\mathrm{X}$ chromosomes (Fig. 2) shows that the position of the centromeres and the pseudoautosomal regions are not conserved between species.

We have observed a 10-fold difference in the recombination frequency between INRA30 and MAF45 in the X chromosome and the Y chromosome. The pseudoautosomal boundary lies between MAF45 and TGLA328, so the recombination frequency difference between the $\mathrm{X}$ and $\mathrm{Y}$ chromosomes from INRA30 to the boundary is $\sim 5$-fold. These observations are consistent with the fact that meiotic exchange in males is confined to this region, whereas in females, exchange can occur over the entire length of the $X$ chromosome. The differences observed in sheep are similar to those observed between the human female and male sex chromosomes (Page et al. 1987). Estimates of genetic map length from five human pseudoautosomal loci were $4-18 \mathrm{cM}$ for female meiosis and $40 \mathrm{cM}$ for male. Although the average recombination frequencies are $\sim 10$-fold lower in the pseudoautosomal region of the human $X$ chromosome compared with the $Y$ chromosome, some regions close to the $\mathrm{X}$ chromosome pseudoautosomal telomere have similar recombination rates, which are similar to the recombination rates observed at the $\mathrm{Y}$ chromosome telomeric region (Henke et al. 1993). More ovine pseudoautosomal markers would be needed to determine whether this gradient of recombination occurs across this ovine pseudoautosomal region.

The cattle and sheep $\mathrm{X}$ chromosomes have been postulated to be related by a pericentric inversion based on comparative data of the chromosomes of cattle, sheep, and goats by both reverse G-banding (Hayes et al. 1991) and GTGbanding (Kaftanovskaya and Serov 1994). With the recent publication of the bovine $\mathrm{X}$ chromosome linkage map, direct comparison with the sheep linkage map is now possible. The cattle map contains 15 microsatellite markers, five of which are present on this sheep $\mathrm{X}$ chromosome map (INRA30, MAF45, TGLA15, TGLA68, and TGLA89). The linkage distances (Kosambi cM) between these markers in both species are almost identical, indicating that the two chromosomes are not rearranged with respect to each other over the regions common to both. The cattle X chromosome map is $20 \mathrm{cM}$ shorter than our sheep map, and this fits with the observation of Yeh et al. (1996) that their linkage map was $~ 30-$ $50 \mathrm{cM}$ shorter that the predicted physical length.

MAF45 is pseudoautosomal in cattle as it is in sheep. Comparison of the banding patterns and genetic linkage maps of sheep and cattle autosomes shows considerable homology, and the difference in chromosome number can be explained by centromeric fusions of smaller cattle chromosomes (Hediger et al. 1991; Echard et al. 1994; Crawford et al. 1995). However, the banding patterns and positions of the centromeres of the sheep and cattle $\mathrm{X}$ chromosomes is quite different, suggesting the independent evolution of the $\mathrm{X}$ chromosome between these two species since they diverged about 20 million years ago (Wilson et al. 1987). Although it is clear that the differences between positions of genes on the human and mouse $X$ chromosomes can be explained by the rearrangement of defined groups of genes, it remains to be answered whether this shuffling of syntenic groups within the $\mathrm{X}$ chromosomes is a common feature or mechanism within the placental mammals. The information provided by the sheep $\mathrm{X}$ chromosome indicates that the evolution of the $\mathrm{X}$ chromosome may be more complex than simple transposition of the syntenic groups identified by comparing mice with humans. Further interpretation awaits mapping data from other mammalian species.

\section{METHODS}

\section{Markers}

A large selection of mammalian X-linked markers were analyzed for their ability to detect RFLPs in sheep DNA. Gene probes for 28 known gene loci from human, mouse, rat, or cattle $\mathrm{X}$ chromosomes were tested on genomic DNA from 5-10 sheep cut with up to 24 different restriction enzymes.

Mouse PROP (properdin P factor) and human STS (steroid sulphatase) showed no homology to sheep DNA. Human HPRT, human MIC2 (surface antigen), human OTC, human PRPS2 (phosphoribosyl pyrophosphate synthetase 


\section{GALLOWAY ET AL.}

2), and human ZFX contained repeated sequences that hybridized to sheep DNA. Human GAPDP1 (glyceraldehyde3-phosphate dehydrogenase pseudogene 1), human G6PD, cattle HRASP (v-Ha-ras oncogene homolog pseudogene), human KAL (Kallman syndrome), human RCP, human SYP (synaptophysin), and human VDAC1 (voltagedependent anion channel 1) hybridized with sheep DNA but showed no polymorphic bands in sheep DNA cut with at least 23 different restriction enzymes.

Human androgen receptor, human BGN (proteoglycan 1 biglycan), and rat PRPS1 (phosphoribosyl pyrophosphate synthetase 1) detected no polymorphic bands with eight restriction enzymes.

Human NDP (Norrie disease, pseudoglioma) detected a HindIII polymorphism that was not X-linked in sheep. Human F9 detected a BglII polymorphism that did not appear to segregate in a Mendelian fashion in our sheep pedigrees. Mouse AMELX (amelogenin) and mouse UBE (ubiquitin activating enzyme) detected MspI and TaqI polymorphisms, respectively, but the presence of conflicting bands in male sheep made unambiguous scoring difficult and these genes were not included. Six anonymous human genomic DNA fragments from the $\mathrm{X}$ chromosome were also tested. All of these hybridized with sheep DNA and all failed to detect polymorphisms in DNA cut with 23 restriction enzymes.

RFLP markers to seven known genes were identified as single copy in sheep and detected polymorphic alleles that could be scored unambiguously (Table 1). X-linked Mendelian inheritance has been demonstrated previously for ATP7A, PHKA1, PLP, TBG, and XIST and was demonstrated in this study for DMD and PDHA1.

A $1.5-\mathrm{kb}$ probe for the E1alpha subunit of PDHA1 was isolated from the EcoRI site of recombinant Bluescribe plasmid PDHE1alpha1c obtained from Dr. H.-H.M. Dahl (Dahl et al. 1987). A HindIII polymorphism detected two allelic bands of $\sim 7.5 \mathrm{~kb}$ (A1) and $2 \mathrm{~kb}$ (A2). Constant bands of $-21,16,5,3.5,3,2.5$, and $1.5 \mathrm{~kb}$ were also detected. The allele frequency in 35 unrelated Coopworth and Romney female sheep was 0.23 (A1) and 0.77 (A2). A 0.9-kb probe for the DMD locus was isolated from the EcoRI site of recombinant SP65 vector Ca1a obtained from Dr. K.E. Davies (K. Davies, pers. comm.) A PvuII polymorphism detected two allelic bands of $6 \mathrm{~kb}$ (A1) and $2.5 \mathrm{~kb}$ (A2). Constant bands of 9.5 and $1.0 \mathrm{~kb}$ were also observed. The allele frequency in 35 unrelated Coopworth and Romney female sheep was 0.51 (A1) and 0.49 (A2). X-linked segregation was observed in the XMF ( $\mathrm{X}$ chromosome Mapping Flock, described below), and none of the males were heterozygous for either PDH or DMD.

$\mathrm{X}$-linked microsatellite (dinucleotide repeat) markers are described in Table 2. OarCP131 was isolated from genomic sheep DNA using the method described in Hanrahan et al. (1994). OarMP4 was derived from DNA from a hamster somatic cell hybrid R612-3B10 (Burkin et al. 1993), containing part of the sheep X chromosome (S.M. Galloway, unpubl.).

DNA extraction from sheep whole blood was carried out as described previously (Montgomery and Sise 1990). Southern blotting, identification of polymorphisms and RFLP analysis was as described in Montgomery et al. (1992), using the hybridization conditions described in Broom and Penty (1993). Microsatellite alleles were amplified and analyzed as described previously (Crawford et al. 1994).

\section{Flocks}

Linkage relationships were observed in the $X$ chromosome Mapping Flock (XMF), which contained 480 animals in a three-generation family structure. Ten Romney rams in the first generation were mated naturally to Romney ewes to produce 145 female offspring in the second generation. These 145 female offspring were mated naturally to 14 Romney rams to produce 207 female and 104 male offspring in the third generation (maximum of 912 possible informative meioses). No DNA was collected from the Romney ewes in the first generation. Correct parentage was confirmed by the consistent Mendelian segregation of all 21 markers. Two of the probes, INRA30 and XIST, were genotyped over a subset of the XMF pedigree consisting of 197 animals in a three-generation flock structure. This subset included 9 rams mated to Romney ewes to produce 80 female offspring that were then mated to 10 rams in the second generation to produce 98 female offspring (maximum 256 possible informative meioses).

Additional mapping data was obtained for some probes (INRA30, MAF45, OarAE25, OarAE133, OarMP4, PLP, TBG, TGLA15, and XIST) by genotyping them in the AgResearch International Mapping Flock (IMF), which contained 127 animals in nine related three-generation full-sib pedigrees with a maximum of 222 possible informative meioses (Crawford et al. 1995). BM861, OarCP131, and TGLA328 were genotyped solely in the IMF.

\section{Linkage Mapping}

Genotype data from all markers was scored independently by two people. The pedigrees were verified by confirming Mendelian inheritance of the markers from putative parents. The scores for each additional marker were checked for consistency with the verified pedigree records. Xlinked markers were assigned to the $X$ chromosome by observation of complete cosegregation with sex and the observation of heterozygosity in some females but none of the males in the sheep pedigrees. Pseudoautosomal markers were distinguished from autosomal markers and assigned to the $\mathrm{X}$ chromosome by the observation of significant linkage with sex or with markers assigned previously to the $\mathrm{X}$ chromosome.

Multipoint linkage analysis was performed with the BUILD option of CRI-MAP (Lander and Green 1987) allowing for sex-specific recombination rates. A dummy allele was created and assigned as the second allele for all males, for each non-pseudoautosomal marker. Double recombinants were detected using the CHROMPIC option with the most likely order. The scores of any genotypes resulting in multiple recombination over short distances were rechecked and regenotyped if unresolved.

The map positions from the BUILD option of CRIMAP were checked using the FLIPS6 option to ensure that the odds in favor of the framework order presented were at least 1000:1 over the alternative orders checked. Additional checks for linkage group membership, as detailed in Crawford et al. (1995) were performed. Map distances were estimated using the Kosambi mapping function.

\section{ACKNOWLEDGMENTS}

We gratefully acknowledge George Davis and Arnold Gray for providing the animals used in the mapping pedigrees, 


\section{OVINE X CHROMOSOME MAP}

Anne Beattie for flock maintenance and blood sampling, Jude Sise for initial development of flock structure and probes, and Dr. Grant Montgomery for ongoing advice. Dr. H.-H. Dahl provided the PDHA1 probe and Dr. K. Davies, the DMD probe. Funding has been provided from the New Zealand Foundation for Research, Science and Technology through AgResearch, and the New Zealand Lotteries Grants Board. The sequence data described in this paper have been submitted to the GenBank data library under accession numbers U51716 (OarMP4) and U54614 (OarCP131).

The publication costs of this article were defrayed in part by payment of page charges. This article must therefore be hereby marked "advertisement" in accordance with 18 USC section 1734 solely to indicate this fact.

\section{REFERENCES}

Aasen, E. and J.F. Medrano. 1990. Amplification of the ZFY and ZFX genes for sex determination in humans, cattle, sheep and goats. BioTechnology 8: 1279-1281.

Amar, L.C., L. Dandolo, A. Hanauer, A. Ryder-Cook, D. Arnaud, J.-L. Mandel, and P. Avner. 1988. Conservation and reorganisation of loci on the mammalian $\mathrm{X}$ chromosome: A molecular framework for the identification of homologous regions in man and mouse. Genomics 2: 220-230.

Archibald, A.L., C.S. Haley, J.F. Brown, S. Couperwhite, H.A. McQueen, D. Nicholson, W. Coppieters, A. Van de Weghe, A. Stratil, A.K. Wintero, M. Fredholm, N.J. Larsen, V.H. Nielson, D. Milan, N. Woloszyn, A. Robic, M. Dalens, J. Riquet, J. Gellin, J.C. Caritez, G. Burgaud, L. Olliver, J.P. Bidanel, M. Vaiman, C. Renard, H. Geldermann, R. Davoli, D. Ruyter, E.J.M. Verstege, M.A.M. Groenen, W. Davies, B. Hoyheim, A. Keiserud, L. Andersson, H. Ellegren, M. Johanssen, L. Marklund, J.R. Miller, D.V. Anderson Dear, E. Signer, A.J. Jeffreys, C. Moran, P. Le Tissier, P. Muladno, M.F. Rothschild, C.K. Tuggle, D. Vaske, J. Helm, H.-C. Liu, A. Rahman, T.-P. Yu, R.G. Larson, and C.B. Schmitz. 1995. The PiGMaP consortium linkage map of the pig (Sus scrofa). Mamm. Genome 6: 157-175.

Backfisch, W., S. Neuenschwander, U. Giger, G. Stranzinger, and V. Pliska. 1994. Carrier detection of ovine Haemophilia A using an RFLP marker, and mapping of the Factor VIII gene on the ovine X-chromosome. J. Hered. 85: 474-478.

Barendse, W., S.M. Armitage, L.M. Kossarek, A. Shalom, B.W. Kirkpatrick, A.M. Ryan, D. Clayton, L. Li, H.L. Neibergs, N. Zhang, W.M. Grosse, J. Weiss, P. Creigthon, F. McCarthy, M. Ron, A.J. Teale, R. Fries, R.A. McGraw, S.S. Moore, M. Georges, M. Soller, J.E. Womack, and D.J.S. Hetzel. 1994. A genetic linkage map of the bovine genome. Nature Genet. 6: 227-235.

Bishop, M.D., S.M. Kappes, J.W. Keele, R.T. Stone, S.L.F. Sunden, G.A. Hawkins, S. Solinas-Toldo, R. Fries, M.D.
Grosz, J. Yoo, and C.W. Beattie. 1994. A genetic linkage map for cattle. Genetics 136: 619-639.

Blair, H.J., V. Reed, S.H. Laval, and Y. Boyd. 1994. New insights into the man-mouse comparative map of the $\mathrm{X}$ chromosome. Genomics 19: 215-220.

Blair, H.J., M. Ho, A.P. Monaco, S. Fisher, I.W. Craig, and Y. Boyd. 1995. High-resolution comparative mapping of the proximal region of the mouse $\mathrm{X}$ chromosome. Genomics 28: 305-310.

Botstein, D., R.L. White, M. Skolnick, and R.W. Davis. 1980. Construction of a genetic linkage map in man using restriction fragment length polymorphism. Am. J. Hum. Genet. 32: 314-331.

Broom, J.E. and J.M. Penty. 1993. A Msp I RFLP at the ovine protein kinase C beta locus. Anim. Genet. 24: 146.

Brown, C.J., A. Ballabio, J.L. Rupert, R.G. Lafreniere, M. Grompe, R. Tonlorenzi, and H.F. Willard. 1991. A gene from the region of the human $\mathrm{X}$-inactivation centre is expressed exclusively from the inactive $\mathrm{X}$ chromosome. Nature 349: 38-44.

Burkin, D.J., H.G. Morse, T.E. Broad, P.D. Pearce, H.A. Ansari, P.E. Lewis, and C. Jones. 1993. Mapping the sheep genome: Production of characterized sheep $\mathrm{X}$ hamster cell hybrids. Genomics 16: 466-472.

Chapman, H.M. and A.N. Bruere. 1977. Chromosome morphology during meiosis of normal and Robertsonian translocation-carrying rams (Ovis aries). Can. J. Genet. Cytol. 19: 93-102.

Ciampolini, R., K. Goudarzi, D. Vaiman, and H. Leveziel. 1993. A new bovine dinucleotide repeat microsatellite: Microsatellite INRA 30. Anim. Genet. 24: 221.

Cooper, P., J.T. Keer, V.M. McCabe, R.M.J. Hamvas, S.D.M. Brown, S. Rastan, and N. Brockdorff. 1993. Physical mapping of $2000 \mathrm{~kb}$ of the mouse $\mathrm{X}$ chromosome in the vicinity of the XIST locus. Genomics 15: $570-575$.

Crawford, A.M., K.G. Dodds, A.J. Ede, C.A. Pierson, G.W. Montgomery, H.G. Garmonsway, A.E. Beattie, K. Davies, J.F. Maddox, S.W. Kappes, R.T. Stone, T.C. Nguyen, J.M. Penty, E.A. Lord, J.E. Broom, J. Buitkamp, W. Schwaiger, J.T. Epplen, P. Matthew, M.E. Matthews, D.J. Hulme, K.J. Beh, R.A. McGraw, and C.W. Beattie. 1995. An autosomal genetic linkage map of the sheep genome. Genetics 140: 703-724.

Crawford, A.M., G.W. Montgomery, C.A. Pierson, T. Brown, K.G. Dodds, S. Sunden, H.M. Henry, A.J. Ede, P.A. Swarbrick, T. Berryman, J.M. Penty, and D.F. Hill. 1994. Sheep linkage mapping: Nineteen linkage groups derived from the analysis of paternal half-sib families. Genetics 137: 573-579.

Dahl, H.-H.M., S.M. Hunt, W.M. Hutchison, and G.B. 


\section{GALLOWAY ET AL.}

Brown. 1987. The human pyruvate dehydrogenase complex. J. Biol. Chem. 262: 7398-7403.

Dahl, H.-H.M., R.M. Brown, W.M. Hutchison, C. Maragos, and G.K. Brown. 1990. A testis-specific form of the human pyruvate dehydrogenase E1a subunit is coded for by an intronless gene on chromosome 4 . Genomics 8: 225-232.

Dai, K., A.E. Dollin, and C.B. Gillies. 1994. Synaptonemal complex analysis of domestic sheep (Ovis aries) with Robertsonian translocations. Genome 37: 672-678.

Davis, G.H., J.C. McEwan, P.F. Fennessy, K.G. Dodds, and P.A. Farquhar. 1991. Evidence of the presence of a major gene influencing ovulation rate on the $\mathrm{X}$ chromsome of sheep. Biol. Reprod. 44: 620-624.

Echard, G., T.E. Broad, D.F. Hill, and P. Pearce. 1994. Present status of the ovine gene map (Ovis aries); comparison with the bovine map (Bos taurus). Mamm. Genome 5: 324-332.

Eggen, A. and R. Fries. 1995. An integrated cytogenetic and meiotic map of the bovine genome. Anim. Genet. 26: $215-236$.

Fitzgerald, J., S.A. Wilcox, J.A. Marshall Graves, and H.M. Dahl. 1993. A eutherian X-linked gene, PDHA1, is autosomal in marsupials: A model for the evolution of a second, testis-specific variant in eutherian mammals. Genomics 18: 636-642.

Freije, D., C. Helms, M.S. Watson, and H. Donis-Keller. 1992. Identification of a second pseudoautosomal region near the Xq and Yq teleomeres. Science 258: 1784-1787.

Fries, R., A. Eggen, and J.E. Womack. 1993. The bovine genome map. Mamm. Genome 4: 405-428.

Georges, M. and J. Massey. 1992. Polymorphic DNA markers in Bovidae. World Intellectual Property Organization Geneva, Switzerland. W O Publ. no. 92/13102.

Graves, J.A.M. and J.W. Foster. 1994. Evolution of mammalian sex chromosomes and sex-determining genes. Int. Rev. Cytol. 154: 191-259.

Hanrahan, V., J.A. Sise, and D.F. Hill. 1992. A Msp I polymorphisim at the ovine thyroxine binding globulin locus. Anim. Genet. 23: 293.

Hanrahan, V., A. Ede, and A.M. Crawford. 1994. Ovine $\mathrm{X}$-chromosome microsatellites at the OarAE25 and OarAE133 loci. An. Genet. 25: 370.

Hayes, H., E. Petit, and B. Dutrillaux. 1991. Comparison of RBG-banded karyotypes of cattle, sheep, and goats. Cytogenet. Cell Genet. 57: 51-55.

Hediger, R., H.A. Ansari, and G.F. Stranzinger. 1991. Chromosome banding and gene localizations support extensive conservation of chromosome structure between cattle and sheep. Cytogenet. Cell Genet. 57: $127-134$.

Henke, A., C. Fischer, and G.A. Rappold. 1993. Genetic map of the human pseudoautosomal region reveals a high rate of recombination in female meiosis at the $\mathrm{Xp}$ teleomere. Genomics 18: 478-485.

Herman, G.E., Y. Boyd, V. Chapman, A. Chatterjee, and S.D.M. Brown. 1994. Mouse X chromosome. Mamm. Genome 5: s276-s288.

Jacob, H.J., D.M. Brown, R.K. Bunker, M.J. Daly, V.J. Dzau, A. Goodman, G. Koike, V. Kren, T. Kurtz, A. Lernmark, G. Levan, Y. Mao, A. Pettersson, M. Pravenec, J.S. Simon, C. Szpirer, J. Szpirer, M.R. Trolliet, E.S. Winer, and E.S. Lander. 1995. A genetic linkage map of the laboratory rat, Rattus norvegicus. Nature Genet. 9: 63-69.

Kaftanovskaya, H.M. and O.L. Serov. 1994.

High-resolution GTG-banded chromosomes of cattle, sheep and goat: A comparative study. J. Heredity 85: 395-400.

Kemp, S.J., L. Brezinsky, and A.J. Teale. 1993. A panel of bovine, ovine and caprine polymorphic microsatellites. Anim. Genet. 24: 363-365.

Lafreniere, R.G., C.J. Brown, S. Rider, J. Chelly, P. Taillon-Miller, A.C. Chinault, A.P. Monaco, and H.F. Willard. 1993. 2.6 Mb YAC contig of the human $\mathrm{X}$-inactivation center region in Xq13: Physical linkage of the RPS4X, PHKA1, XIST and DXS128E genes. Hum. Mol. Genet. 2: 1105-1115.

Lander, E.S. and P. Green. 1987. Construction of multilocus genetic linkage maps in humans. Proc. Natl. Acad. Sci. 84: 2363-2367.

Laval, S.H. and Y. Boyd. 1993a. Partial inversion of gene order within a homologous segment on the $\mathrm{X}$ chromosome. Mamm. Genome 4: 119-123.

1993b. Novel sequences conserved on the human and mouse X chromosomes. Genomics 15: $483-491$.

McKay, L.M., J.M. Watson, and J.A.M. Graves. 1992. Mapping human X-linked genes in the Phalangerid marsupial Trichosurus vulpecula. Genomics 14: 302-308.

Montgomery, G.W. and J.A. Sise. 1990. Extraction of DNA from sheep white blood cells. N.Z. J. Ag. Res. 33: $437-441$.

Montgomery, G.W., J.A. Sise, J.M. Penty, H.M. Tou, and D.F. Hill. 1992. Sheep linkage mapping: Restriction fragment length polymorphism detection with heterologous cDNA probes. Anim. Genet. 23: 411-416.

O'Brien, S.J. 1993. Anchored reference loci for comparative gene mapping in mammals. Nature Genet. 3: $103-112$. 


\section{OVINE X CHROMOSOME MAP}

Ohno, S. 1973. Ancient linkage groups and frozen accidents. Nature 244: 259-262.

Page, D.C., K. Bieker, L.G. Brown, S. Hinton, M. Leppert, J.-M. Lalouel, M. Lathrop, M. Nystrom-Lahti, A. de la Chapelle, and R. White. 1987. Linkage, physical mapping, and DNA sequence analysis of pseudoautosomal loci on the human $X$ and $Y$ chromosomes. Genomics 1: 243-256.

Palmer, S., J. Perry, and A. Ashworth. 1995. A contravention of Ohno's law in mice. Nature Genet. 10: $472-476$.

Potts, M.D., V. Hanrahan, and D.F. Hill. 1994a. A Bgl II polymorphism at the ovine phosphorylase kinase alpha subunit locus (PHKA1). Anim. Genet. 25: 288.

1994b. An Eco RV polymorphism at the ovine Menkes disease locus (ATP7A). Anim. Genet. 25: 293.

Rohrer, G.A., L.J. Alexander, J.W. Keele, T.P. Smith, and C.W. Beattie. 1994. A microsatellite linkage map of the porcine genome. Genetics 136: 231-245.

Rugarli, E.I., D.A. Adler, G. Borsani, K. Tsuchiya, B. Franco, X. Hauge, C. Disteche, V. Chapman, and A. Ballabio. 1995. Different chromosomal localization of the Clcn4 gene in Mus spretus and C57BL/6J mice. Nature Genet. 10: $466-470$.

Saidi-Mehtar, N., M.C. Hors-Cayla, and N.V. Cong. 1981. Sheep gene mapping by somatic cell hybridization: Four syntenic groups: ENO1-PGD, ME1-PGM3,

LDHB-PEPB-TPI, G6PD-PGK-GALA. Cytogenet. Cell Genet. 30: $193-204$.

Saidi-Mehtar, N., M. Imam Ghali, S. Heuertz, and M.C. Hors-Cayla. 1989. Sheep gene mapping by somatic cell hybridization. Cytogenet. Cell Genet. 51: 1072.

Sise, J.A., V. Hanrahan, and D.F. Hill. 1992. A Msp I polymorphism at the proteolipid protein locus (PLP). An. Genet. 23: 292.

Sise, J.A., V. Hanrahan, G.W. Montgomery, and D.F. Hill. 1994. Genetic linkage of proteolipid protein (PLP) and thyroxine-binding globulin (TBG) on the ovine $X$ chromosome. Cytogenet. Cell Genet. 66: 250-252.

Swarbrick, P.A., A.E. Schmack, and A.M. Crawford. 1992. MAF45, a highly polymorphic marker for the pseudoautosomal region of the sheep genome, is not linked to the FecX1 (Inverdale) gene. Genomics 13: $849-851$.

van Stijn, T. and S. Galloway. 1995. A Bam HI polymorphism at the ovine inactive X-specific transcript locus (XIST). Anim. Genet. 26: 279.

Willard, H.F., F. Cremers, J.L. Mandel, A.P. Monaco, D.L. Nelson, and D. Schlessinger. 1994. Report of the Fifth International Workshop on Human X Chromosome Mapping. Cytogenet. Cell Genet. 67: 295-358.
Wilson, A.C., H. Ochman, and E.M. Prager. 1987. Molecular time scale for evolution. Trends Genet. 3: $241-247$.

Yeh, C.C., J.F. Taylor, D.S. Gallagher, J.O. Sanders, J.W. Turner, and S.K. Davis. 1996. Genetic and physical mapping of the bovine X chromosome. Genomics 32: $245-252$.

Yerle, M., Y. Lahbib-Mansais, C. Mellink, A. Goureau, P. Pinton, G. Echard, J. Gellin, C. Zijlstra, N. De Haan, A.A. Bosma, B. Chowdhary, F. Gu, I. Gustavsson, P.D. Thomsen, K. Christensen, G. Rettenberger, H. Hameister, A. Schmitz, B. Chaput, and G. Frelat. 1995. The PiGMaP consortium cytogenetic map of the domestic pig (Sus scrofa domestica). Mamm. Genome 6: 176-186.

Received January 24, 1996; accepted in revised form June 11, 1996. 


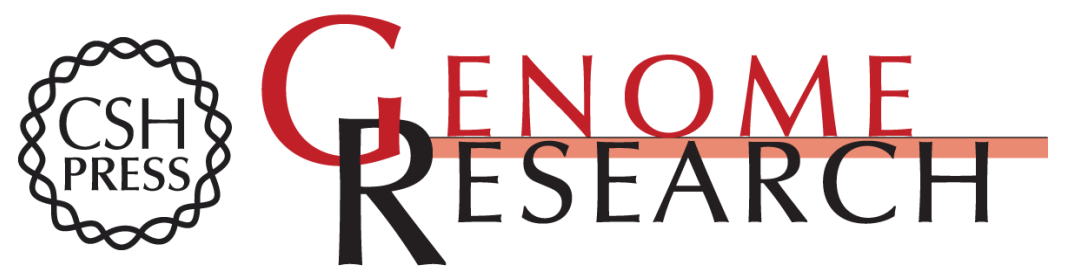

\section{A linkage map of the ovine $X$ chromosome.}

S M Galloway, V Hanrahan, K G Dodds, et al.

Genome Res. 1996 6: 667-677

Access the most recent version at doi:10.1101/gr.6.8.667

References This article cites 61 articles, 7 of which can be accessed free at:

http://genome.cshlp.org/content/6/8/667.full.html\#ref-list-1

\section{License}

Email Alerting Receive free email alerts when new articles cite this article - sign up in the box at the Service top right corner of the article or click here.

\section{Affordable, Accurate Sequencing.}

To subscribe to Genome Research go to: https://genome.cshlp.org/subscriptions 